\title{
Teachers Perception on the Development of Mathematics Teaching Materials on Social Arithmetic Based on Guided Inaquiry for Deaf Students of Class X at SLB Budi Mulia
}

\author{
Mahura Mayang Sari ${ }^{*}$; Muhammad Akhyar; Munawir Yusuf \\ Universitas Sebelas Maret \\ Email: mahuramayang@gmail.com
}

http://dx.doi.org/10.18415/ijmmu.v5i5.558

\begin{abstract}
This research aimed to describe teacher's perception on the development of mathematics teaching materials on social arithmetic based on guided inquiry for the deaf students of class X at SLB Budi Mulia. This research was qualitative research. Technique of data collection used were in-depth interview and non-participant observation. Subject of research was a Mathematics teacher in SLB Budi Mulia that has implemented 2013 curriculum. The results showed positive perceptions on Mathematics teaching materials on social arithmetic based on guided inquiry in which teaching materials have contained scientific approach learning as well as characteristics of guided inquiry model
\end{abstract}

Keywords: Teachers Perception; Mathematics Teaching Material; Social Arithmetic; Guided Inquiry; Deaf Students; 2013 Curricu-Lum

\section{Introduction}

The initial launch of 2013 curriculum is inseparable from pessimistic and optimistic education world. It is pessimistic due to the cognitive aspect, heavy burden for students and less character content. The preparation of 2013 curriculum is also considered too hasty and does not refer to the results of existing studies based on the evaluation results of KTSP, and pays little attention to teachers' readiness and education units. On the other hand, the optimistic perception of education world believes that 2013 curriculum will be able to overcome unresolved problems in KTSP so that the quality of education programs in Indonesia could be better. This is supported by the research on Teachers' Perception on KTSP 2006 and 2013 Curriculum at SMA/MA in Pontianak conducted by Fallo, et al (2017). They argue that teachers' perception on 2013 curriculum is better that teachers' perception on KTSP 2016 because 2013 Curriculum is more detail and effective to improve students' learning outcomes. It also enables teacher to be more competent in their field.

The quality of education program is influenced by several factors such as students, the quality of teacher, the availability of teaching materials, curriculum, facilities, learning media completeness and management. In 2013 curriculum, government has provided learning material books consisting of teacher books and student books as one of compulsory learning source books at school including for deaf 
students. On the introduction of teacher and student books for deaf students, it is described the effort that must be enforced by deaf students to reach an expected competence. In 2013 curriculum, teacher and students are encouraged to find other earning sources. This is because the books that have been provided by the Government are intended for national scale purposes, which means that teacher books and student books are generally made for all deaf students' condition in Indonesia. Considering the diverse characteristics of deaf students in Indonesia, it could not accommodate the special needs of each school yet. It is in line with the research conducted by Darius (2014) related to teacher's perception on Mathematics materials in teacher and student books of class IV, V, VI 2013 curriculum in Delima cluster Banda Aceh. The result shows that $51.39 \%$ of respondents in Delima cluster Banda Aceh stated that several materials in teacher and student books are still incomplete yet and it is difficult to understand by the students. Therefore, it can be concluded that the existence of teacher and student books specifically for Mathematics material is not fully good and acceptable by the students. Due to this problem, it is required companion learning material for books from government to support learning process that is appropriate for deaf students' characteristics.

Mathematics is a science field that trains reasoning to be logical and systematic in solving problems. Learning Mathematics needs particular way because Mathematics itself is distinctive that is abstract, consistent, and deductive thinking Hudojo in Susilawati and Samsul, (2016). Mathematics is one of lessons that plays important role in education. Because of the essence of Mathematics, it is a must for everyone to earn Mathematics. As the phrase "education for all", there is no exception for all students including deaf students to learn Mathematics. Social Arithmetic materials appears in National Examination items that have to be accomplished by deaf students. Social arithmetic materials are important because it is related to daily activities of deaf students. To learn more deeply and understand social arithmetic material, the researcher develops Mathematics teaching material on social arithmetic based on guided inquiry for deaf students of class X. By implementing guided inquiry, it is expected that with teachers' guidance, deaf students will be able to find it themselves and save it in long term memory.

Teacher's knowledge and understanding related to Mathematics teaching materials on arithmetic based on guided inquiry for deaf students in class $\mathrm{X}$ is extremely important in conducting Mathematics learning activities. The perception of each Mathematics teacher will be various. In conducting perceptions, there is an indicator, namely acceptance by the sensory devices, so that they can get an overview of Mathematics teaching material on social arithmetic based on guided inquiry. After gaining the overview, an understanding of teaching materials will be formed, then it is followed by assessment and evaluation. The more positive the teacher's perception on Mathematics teaching materials on social arithmetic based on guided inquiry is, the availability of Mathematics teaching materials in the 2013 curriculum will be acceptable. Besides, the application of teaching materials in learning process is better. In line with those statements, Musanni, et al (2014) confirm that teaching material really determines the success of student education in the learning process at school. Therefore, good and high qualified teaching material is not only a source of knowledge that can bolster the success of students learning, but also it guides and directs learning process to the excellent learning process. Conversely, the more negative the teacher's perception on Mathematics teaching materials is, less acceptable, the application of teaching materials in learning process is getting worse.

Based on interviews with Mathematics teachers at SLB Budi Mulia, Blitar regarding teacher perceptions on Mathematics teaching materials on social arithmetic based on guided inquiry in the 2013 curriculum for deaf students, the perceptions conveyed by Mathematics teachers were different. For that reason, the researcher was interested to conduct further research regarding teacher perception on Mathematics teaching material on social arithmetic based on guided inquiry in the 2013 curriculum.

\section{Methodology}


This research applied qualitative approach. It was descriptive qualitative research. This research deeply describes the important aspects related to the research objectives, so that a comprehensive description of teacher perceptions on Mathematics teaching material on social arithmetic based on guided inquiry in the 2013 curriculum for deaf student of class X at SLB Budi Mulia is obtained.

Subjects of the research were the Mathematics teachers at SLB Budi Mulia that has applied the 2013 curriculum. Techniques of data collection were in-depth interview and non-participant observation. In-depth interview was conducted face to face with the teachers. Direct and non-participant observation was conducted directly by the researcher to observe Mathematics learning activities using Mathematics teaching materials on social arithmetic based on guided inquiry for deaf students of class X at SLB Budi Mulia without participating learning process. Through observation process, the researcher knew the truth of the real answer. In conducting observation in this research, the researcher observed how teacher applied Mathematics teaching material on social arithmetic based on guided inquiry for the deaf students of class in learning process. The research instruments used were video to record interview process, note book to write interview results and field notes to note observation result during the observation in classroom. Technique of data analysis used was interactive model proposed by Miles and Huberman in Sugiyono (2012: 337-345) that consists of data reduction, data display and conclusion drawing/verifying. This research applied triangulation to test the validity of data and to enrich data.

\section{Result and Discussion}

The government has provided books for teaching and learning process in implementing the 2013 curriculum. However, the books used pay less attention to teachers needs and characteristics of deaf students. In the learning process that is in accordance with the development of science and technology, the use of various learning resources is extremely required. This is in line with Winna Sanjaya (2014: 175) that argues that learning resources that can be utilized by teachers in the learning process include human beings, tools in the form of print and audio-visual media, activities, and environment Therefore, Mathematics teaching materials that are appropriate to the teachers needs and characteristic of deaf students are arranged.

The observation results showed that the utilization of Mathematics teaching materials on social arithmetic based on guided inquiry for the deaf students of class $X$ at SLB Budi Mulia has been appropriate with the 2013 curriculum. The 2013 curriculum is more maximal by using the development of Mathematics teaching material on social arithmetic based on guided inquiry. Learning activities assisted by the Mathematics teaching materials are carried out by observing aspects of observing activities, presenting questions or formulating problems, formulating hypotheses, conducting investigations, collecting and analysing data and making conclusions.

The interview results with teachers who teach Mathematics show that by using Mathematics teaching materials based on guided inquiry, the activities of students' inquiry become easier to understand and actively participate by using all of their senses and knowledge to find information on social arithmetic material. Positive perceptions of Mathematics teaching material on social arithmetic based on guided inquiry are teaching materials have contained scientific approach learning and the content contains the characteristics of the guided inquiry model. The presentation of teaching materials by paying attention to the scientific approach stages in learning can help teachers to carry out directed learning on social arithmetic teaching materials based on guided inquiry. Scientific approach leaning stages on social arithmetic teaching materials based on guided inquiry can be systematically appeared by the teachers. So that all of learning stages can be appeared by the teacher. 
The display of social arithmetic teaching materials based on guided inquiry is displayed with colours and accompanied by supported contextual images. These images function to ease students in understanding the questions and in the process of solving social arithmetic problems given. From the result of learning process observation, the students are more enthusiastic on teaching materials with a colourful and attractive appearance.

\section{Conclusion}

From the results of research on teachers' perceptions of the development of Mathematics teaching materials based on guided inquiry for the deaf students of class X at SLB Budi Mulia, it can be seen that Mathematics teachers have positive perceptions in which teaching materials have contained scientific approach learning and the content has contained the characteristics of guided inquiry model. Social arithmetic teaching materials based on guided inquiry are expected to be one of the supporting factors for the success of students. By using the Mathematics teaching materials, teachers should be able to develop themselves so that the lack of teaching materials can be regenerated through the revisions made.

\section{Acknowledgment}

The authors wish to thank Muhammad Akhyar and Munawir Yusuf fora great cooperation during the research. Also, for my lovely family for the prayer and support. May Allah bless you.

\section{References}

Darius, Said. (2014). Persepsi guru Terhadap Materi Matematika di Buku guru dan Buku Siswa kelas IV, V, VI pada kurikulum 2013 di Gugus Delima Kota Banda Aceh. Jurnal Pesona Dasar, 2(3): 57-64.

Fallo, Beadryx Otte; Simanjutak, Victor, \& Supritna, Eka. (2017). Persepsi Guru SMA/ MA Kota Pontianak Terhadap KTSP 2006 dan Kurikulum 2013. Jurnal Pesona Dasar, 1: 1-12.

Musanni, Susilawati Susilawati, Aos Santosa Hadiwijaya Hadiwijaya. (2014). Effect of Catalystin Synthesis Polyoycore of Oil Seeds Kenari (Canarium commune) Method Epoxidation. Jurnal Penelitian, 18(1).

Susilawati, Samsul. (2016). Pengembangan Koopeatif Tipe Jigsaw dalam Pembelajaran IPS di Madrasah Ibtidaiyah. JournalIslamic Elementary School, 1(2): 1-6.

Sanjaya, Winna. (2014). Strategi Pembelajaran Berorientasi Standar Proses Pendidika. Jakarta: Kencana Prenada Media Group.

Shadiq, Fadjar, Pembelajaran Matematika. Yogyakarta: Graha Ilmu, 2014.

Sugiyono, Metode Penelitian Pendidikan. Bandung: Alfabeta, 2012.

\section{Copyrights}

Copyright for this article is retained by the author(s), with first publication rights granted to the journal. 
This is an open-access article distributed under the terms and conditions of the Creative Commons Attribution license (http://creativecommons.org/licenses/by/4.0/). 